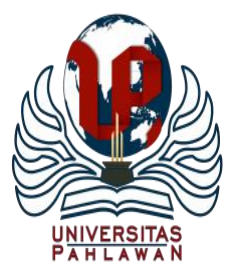

Jurnal Abdidas Volume 2 Nomor 3 Tahun 2021 Halaman 652-661

JURNAL ABDIDAS

http://abdidas.org/index.php/abdidas

\title{
Pendampingan Menulis Esai Sejarah bagi Kelompok Musyawarah Guru Mata Pelajaran (MGMP) Sejarah SMA di Kota Lubuklinggau
}

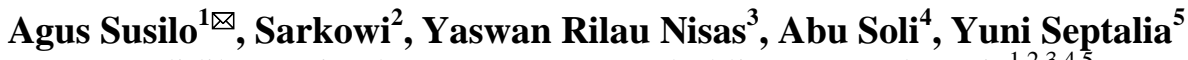 \\ Pendidikan Sejarah, STKIP PGRI Lubuklinggau, Indonesia ${ }^{1,2,3,4,5}$ \\ E-mail: agussusilo4590@gmail.com ${ }^{1}$, sarkowisulaiman@gmail.com ${ }^{2}$, yaswanrilau@gmail.com ${ }^{3}$, \\ Abusoli94@gmail.com ${ }^{4}$, yuniseptalia05@gmail.com ${ }^{5}$
}

\begin{abstract}
Abstrak
Alasan memilih topik pelatihan menulis esai Sejarah adalah sebagai langkah untuk menambah pengalaman bagi Guru-guru Sejarah SMA di Lubuklinggau agar dapat memiliki keterampilan tambahan dalam mengembangkan karya ilmiah esai. Tim pelaksana melakukan kegiatan pengabdian kepada masyarakat dengan tema pelatihan esai didasarkan pengalaman sebagai instruktur esai nasional yang mendapatkan pelatihan dari Guru Mengajar untuk Nusantara. Dalam kegiatan pengabdian kepada masyarakat ini, tim pelaksana menggunakan metode yang berbentuk pendampingan dengan mendampingi guru-guru yang tergabung dalam Musyawarah Guru Mata Pelajaran (MGMP) Sejarah SMA di Kota Lubuklinggau untuk lebih berinovatif dalam mengembangkan diri. Esai adalah tulisan yang sederhana, namun membutuhkan ketelitian agar dapat menjadi karya ilmiah yang baik. Hasil dari kegiatan pengabdian kepada masyarakat ini menghasilkan bahwa semangat Guru Sejarah SMA semakin tinggi untuk terus belajar. esai Sejarah dinilai sangat mudah, namun membutuhkan kejelian agar dapat dipertahankan keasliannya. Antusias dalam pendampingan ini memunculkan tanya jawab tentang esai tersebut. Pelaksanaan pendampingan menulis esai ini dilaksanakan selama dua hari untuk memaksimalkan waktu yang ada. Simpulan dari kegiatan ini adalah pendampingan menulis esai Sejarah sangat bermanfaat bagi guru. Pengalaman yang baru dapat muncul dari pendampingan tersebut. Di era globalisasi memang guru harus terus berinovasi agar dapat menjaga eksistensi dalam pengajaran.
\end{abstract}

Kata kunci: pendampingan, esai, MGMP sejarah

\section{Abstract}

The reason for choosing the topic of historical essay writing training is as a step to add experience for high school history teachers in Lubuklinggau so that they can have additional skills in developing scientific essays. The implementing team carried out community service activities with the theme of sssay training based on experience as a national essay instructor who received training from Teaching Teachers for the Archipelago. In this community service activity, the implementing team uses a method in the form of mentoring by assisting teachers who are members of the High School History Subject Teacher Conference (MGMP) in Lubuklinggau City to be more innovative in developing themselves. An essay is a simple piece of writing, but it requires precision in order to become a good scientific work. The results of this community service activity resulted in a higher high school history teacher's enthusiasm to continue learning. Historical essays are considered very easy but require carefulness in order to maintain their authenticity. Enthusiasm in this assistance led to questions and answers about the essay. The implementation of this Essay writing assistance was carried out for two days to maximize the available time. The conclusion of this activity is that mentoring in writing historical essays is very useful for teachers. New experiences can emerge from this assistance. In the era of globalization, teachers must continue to innovate in order to maintain their existence in teaching.

Keywords: mentoring, essays, history MGMP

Copyright (c) 2021 Agus Susilo, Sarkowi, Yaswan Rilau Nisas, Abu Soli, Yuni Septalia

$\triangle$ Corresponding author

Address : Lubuklinggau

Email : agussusilo4590@gmail.com

ISSN 2721- 9224 (Media Cetak)

DOI : https://doi.org/10.31004/abdidas.v2i3.331

ISSN 2721- 9216 (Media Online)

Jurnal Abdidas Vol 2 No 3 Tahun 2021 p-ISSN 2721-9224 e-ISSN 2721-9216 
653 Pendampingan Menulis Esai Sejarah Bagi Kelompok Musyawarah Guru Mata Pelajaran (MGMP) Sejarah SMA di Kota Lubuklinggau - Agus Susilo, Sarkowi, Yaswan Rilau Nisas, Abu Soli, Yuni Septalia

DOI: https://doi.org/10.31004/abdidas.v2i3.331

\section{PENDAHULUAN}

Menulis adalah kegiatan yang sangat bagus dalam membentuk diri menjadi pribadi yang produktif. Sebagai penulis, tentunya membutuhkan suatu keterampilan yang baik dalam segi berbahasa, tata tulis, dan hal-hal yang menyangkut kegiatan yang berhubungan dengan menulis. Oleh sebab itu, dengan menulis seseorang akan menjadi lebih produktif dalam menata letak $\mathrm{dn}$ mengkoordinasikan isi dalam tulisannya. Dalam kegiatan menulis, sebenarnya sangat mudah dan tidak membutuhkan waktu yang lama. Namun untuk membentuk jiwa sebagai penulis membutuhkan semangat juang yang sangat tinggi. Menjadi seorang penulis dituntut untuk aktif dalam mengungkapkan sebuah ide, gagasan, pengalaman selama di lapangan atau hasil bacaan, maupun pendapat yang kemudian dikemas dalam sebuah tulisan ilmiah. Ke semua ide yang didapatkan dari hal tersebut didapatkan dari kegiatan gemar membaca. Dalam pengembangannya, kegiatan menulis esai sebenarnya merupakan salah satu langkah yang membentuk keterampilan yang tepat yang terdapat di dalam Garis-garis Besar Program Pengajaran (GBPP) dalam mata kuliah kreatif. Melalui kegiatan menulis esai yang dilakukan oleh seseorang dalam lingkungan pendidikan, sangat penting dan memiliki kedudukan yang sangat baik dalam mengungkapkan gagasan dan masalah pada orang lain. Bagi peserta didik, baik di perguruan tinggi maupun siswa menengah yang memiliki jiwa menulis esai yang baik akan menjadi modal berharga dalam melakukan penulisan karya ilmiah (Mustyka, 2016).
Dalam melakukan kegiatan menulis esai sangat diperlukan semangat yang tinggi. Menulis akan menjadi lebih mudah dan nyaman jika dilakukan dengan tujuan untuk menjadi orang yang kreatif. Segala gagasan dari hasil bacaan maupun hasil diskusi dapat dituangkan menjadi sebuah tulisan. Saat ini, menulis menjadi kebutuhan manusia yang tidak dapat dihindari keberadaannya. Menulis esai bukan berarti tanpa melihat ramburambu penulisannya. Menulis esai tetap harus melihat tata tulis dan bacaannya, sehingga dapat menghindari plagiat tulisan. Maka yang sangat diperlukan bagi seorang yang akan melakukan penulisan sebuah esai harus menguasai gagasan yang akan dituangkan di dalam tulisan tersebut dan mengkoordinasikan secara terstruktur agar menjadi sebuah tulisan ilmiah yang menarik. Pada dasarnya menulis adalah langkah untuk berpikir secara keras dan bekerja untuk menyampaikan suatu pesan di dalam tulisan yang disusun secara komunikatif dan menarik (Anggraini, \& Solihatulmilah, 2020).

Selain menarik, menulis dapat membentuk diri menjadi lebih terampil dan semangat. Keterampilan dalam menulis ini didapatkan dengan bantuan bakat dan praktik yang berkesinambungan. Setelah menjadi seorang penulis, tentunya akan menjadikan diri menjadi lebih bersemangat dan produktivitas meningkat. Esai sendiri merupakan salah satu karangan ilmiah yang didapatkan dari ide si penulis yang dikembangkan dengan sumber-sumber yang ada. Jadi esai dapat dikatakan sebagai karangan non fiksi yang berusaha mengenalkan hal tertentu dengan pandangan penulis secara pribadi. Maka 
654 Pendampingan Menulis Esai Sejarah Bagi Kelompok Musyawarah Guru Mata Pelajaran (MGMP) Sejarah SMA di Kota Lubuklinggau - Agus Susilo, Sarkowi, Yaswan Rilau Nisas, Abu Soli, Yuni Septalia

DOI: https://doi.org/10.31004/abdidas.v2i3.331

tidak mengherankan, jika esai kemudian dijadikan sebagai alat untuk mengukur kemampuan intelegensi seseorang. Menulis esai sendiri berusaha untuk merangkai kata menjadi lebih terarah dan menarik agar karya ilmiah benar-benar bernilai tinggi. Untuk itu, untuk menulis sebuah esai, selain dibutuhkan keterampilan yang bagus, juga dibutuhkan semangat yang bagus juga. Hal ini penting agar esai yang dihasilkan lebih berkualitas. Dalam dunia pendidikan di sekolah, menulis esai merupakan bagian dari pembentukan diri bagi siswa yang didapatkan dengan sistem pembelajaran inovatif. Dalam pembelajaran inovatif, selain siswa dapat aktif menulis, juga akan membentuk jiwa yang kritis dalam mengungkapkan sebuah tulisan ilmiah (Nofiyanti, 2018).

Menulis itu adalah seni yang harus dikembangkan dalam kegiatan akademik yang membutuhkan kerja keras. Menulis esai itu sebenarnya mudah asalkan telaten, ada kemauan yang keras, pengetahuan, kreativitas, tuntas, dan ikhlas. Seni menulis akan menjadi menyenangkan jika dilakukan dengan baik selama proses menulis. Sifat yang kreativitas ini akan muncul dengan rajin melakukan kegiatan menulis. Kreativitas yang termasuk kumpulan dari sikap dan kemampuan dalam membimbing seseorang untuk menghasilkan suatu ide, pikiran, atau imajinasi yang kreatif dengan sangat tinggi. Adanya kemampuan yang memunculkan ide kreatif ini dapat membantu peserta didik dalam menumbuhkan semangat untuk menjadi penulis yang baik. Pada dasarnya menulis esai adalah untuk menghasilkan suatu karya ilmiah yang bernilai. Menulis esai yang sederhana harus dilakukan dengan semangat yang tinggi. Sebenarnya tidak harus memiliki bakat khusus dalam menumbuhkan semangat menulis. Selain kerja keras dalam menulis, seorang penulis juga dituntut untuk menjadi penulis yang cerdas. Hal ini agar dalam menulis esai, tidak mengalami kesulitan dalam menerjemahkan karya-karya lainnya. Adanya semangat kerja keras yang tinggi dan luar biasa akan membuahkan keberhasilan dalam menciptakan tulisan ilmiah (Lubis, 2017).

Dalam menulis esai juga dapat dikaitkan dengan sejarah yang pernah terjadi dimasa lampau. Banyak referensi yang dapat dijadikan sumber untuk menunjang tulisan sejarah tersebut. Sejarah lokal sendiri merupakan sejarah yang terjadi dalam lingkup wilayah atau daerah dan berpengaruh kepada kehidupan nasional. Sejarah lokal ditulis menjadi esai ilmiah untuk memberikan makna tersendiri dalam kajian ilmiah setiap peristiwa yang terjadi di Indonesia. Dalam kajian sejarah, setiap daerah dapat mengembangkan pendidikan Sejarah yang dikembangkan berdasarkan daerahnya masing-masing. Hal ini tentunya menjadi tantangan tersendiri bagi Guru-guru Sejarah dalam mengembangkan materi Sejarah yang penuh semangat dengan jiwa nasionalisme. Adanya penulisan esai Sejarah berarti setiap Guru Sejarah nantinya dapat mengembangkan dan mengajarkan esai Sejarah dengan cakupan yang luas dan tidak satu arah saja. Jika pembelajaran Sejarah yang didesain dengan memberikan sentuhan semangat dalam penulisan esai Sejarah secara toleransi akan menumbuhkan kesadaran 
655 Pendampingan Menulis Esai Sejarah Bagi Kelompok Musyawarah Guru Mata Pelajaran (MGMP) Sejarah SMA di Kota Lubuklinggau - Agus Susilo, Sarkowi, Yaswan Rilau Nisas, Abu Soli, Yuni Septalia

DOI: https://doi.org/10.31004/abdidas.v2i3.331

Sejarah bagi penulis esai yang semakin baik (Jumardi, 2020).

Maka betapa pentingnya kegiatan pengabdian kepada masyarakat ini, tim pelaksana bekerjasama dengan Musyawarah Guru Mata Pelajaran (MGMP) Sejarah SMA di Kota Lubuklinggau. Kegiatan pendampingan ini pada dasarnya berupa pengenalan esai sebagai karya ilmiah yang dapat meningkatkan kreativitas Guruguru Sejarah di Lubuklinggau. Tim pelaksana yang merupakan Dosen Pendidikan Sejarah STKIP PGRI Lubuklinggau yang juga instruktur esai nasional berupa berbagi pengalaman dan pengetahuan terkait penulisan esai. Disisi lain, tema yang diangkat berkaitan dengan keilmuan yaitu Sejarah. Jadi esai yang akan dikembangkan adalah esai Sejarah yang ada di Indonesia. Sejarah tidak akan pernah luntur, namun perlu dikembangkan oleh generasi muda yang ada saat ini. Kreativitas dalam menyajikan esai Sejarah sangat menarik jika dikembangkan dengan penuh semangat. Dalam menulis esai Sejarah, tentunya harus dihayati. Esai Sejarah dalam penulisannya dapat diperoleh sumbernya dari referensi jurnal, buku, web yang terdapat di Google, dan hasil pengamatan selama ini. Dapat disimpulkan menulis esai Sejarah sangat simpel dan mudah jika dilakukan dengan semangat yang tinggi.

\section{METODE}

Memberikan pendampingan bagi Guru-guru Sejarah tingkat SMA di Lubuklinggau dalam menulis esai Sejarah Lokal. Metode yang digunakan dalam kegiatan ini adalah metode praktik secara langsung dan metode ceramah. Kegiatan pengabdian kepada masyarakat ini, dilaksanakan dengan diawali dengan memberikan ceramah dalam bentuk Pendampingan Menulis Esai Sejarah bagi Kelompok Musyawarah Guru Mata Pelajaran (MGMP) Sejarah SMA di Kota Lubuklinggau. Dalam kegiatan pengabdian kepada masyarakat ini, jumlah pesertanya mencapai 20 orang peserta yang terdiri dari Guru Sejarah tingkat SMA di Kota Lubuklinggau. Pemateri, mitra, dan Guru-guru Sejarah berkumpul dalam satu ruangan gedung SMA Negeri 5 Kota Lubuklinggau. Dalam pelaksanaan kegiatan pengabdian kepada masyarakat ini, tetap mematuhi protokol kesehatan di masa pandemik Covid-19.

Pelaksanaan kegiatan pengabdian kepada masyarakat yang bertema Pendampingan Menulis Esai Sejarah bagi Kelompok Musyawarah Guru Mata Pelajaran (MGMP) Sejarah SMA di Kota Lubuklinggau ini dilaksanakan pada hari Selasa dan Rabu tanggal 08-09 Juni 2021. Tempat pelaksanaannya berada di Aula SMA Negeri 5 Lubuklinggau. Dalam kegiatan pengabdian kepada masyarakat ini dilakukan dengan menggunakan metode yang dirangkai dengan sebagaimana mestinya. Pendampingan menulis esai Sejarah ini diharapkan Guru-guru Sejarah SMA yang berada di Lubuklinggau mendapatkan pengalaman baru dalam mengembangkan kreativitasnya. Peserta dalam pendampingan menulis esai Sejarah ini didampingi untuk merancang tulisan ilmiah dari menentukan judul sampai sumber yang akan dipergunakan dalam menulis esai Sejarah. Penting bagi Guru Sejarah untuk tetap kreatif dalam 
656 Pendampingan Menulis Esai Sejarah Bagi Kelompok Musyawarah Guru Mata Pelajaran (MGMP) Sejarah SMA di Kota Lubuklinggau - Agus Susilo, Sarkowi, Yaswan Rilau Nisas, Abu Soli, Yuni Septalia

DOI: https://doi.org/10.31004/abdidas.v2i3.331

membuat karya ilmiah yang ringan. Adanya pendampingan menulis esai Sejarah diharapkan menjadi solusi yang terjadi selama ini. Jika seorang Guru Sejarah memiliki kreativitas yang tinggi dalam menulis sebuah esai Sejarah, berkah ilmunya dapat diterapkan kepada siswanya. Menulis esai sebagai bekal untuk menjadi kreatif yang bermanfaat bila dikembangkan dengan baik. Dalam kegiatan menulis esai Sejarah ini dilakukan dengan persiapan sebagai berikut:

a. Pendampingan tentang beberapa tulisan yang termasuk karya ilmiah.

b. Pendampingan guru untuk menentukan ide atau gagasan yang akan diangkat dalam penulisan esai.

c. Pendampingan mitra dalam mengenalkan esai sejarah bagi guru MGMP Sejarah Lubuklinggau.

d. Pendampingan dalam memberikan wawasan dan pengetahuan untuk Guru-guru sejarah: berbagi informasi, data, pengalaman.

e. Pendampingan menentukan materi esai sejarah dan sumber-sumber referensi yang akan digunakan.

f. Pendampingan mitra dalam menulis esai sejarah bagi guru MGMP Sejarah Lubuklinggau.

g. Diskusi dengan Guru-guru sejarah dan mengevaluasi kegiatan agar mudah dipahami dan dijalankan dengan baik oleh sasaran.

\section{HASIL DAN PEMBAHASAN}

Kegiatan pendampingan menulis esai Sejarah bagi kelompok Musyawarah Guru Mata Pelajaran (MGMP) Sejarah SMA Kota Lubuklinggau ini sangat penting untuk dilakukan. Menulis esai berguna untuk mengembangkan diri guru, khususnya Guru Sejarah. Menulis esai berbeda dengan menulis karya ilmiah lainnya. Esai Sejarah dikatakan lebih mudah karena data dapat diperoleh melalui sumber apapun. Selain dapat diperoleh melalui sumber bebas, esai Sejarah juga harus menghindari plagiarisme. Saat ini esai Sejarah merupakan kegiatan positif dalam mengembangkan kreativitasnya. Di era globalisasi saat ini, pengembangan diri bagi guru dapat dilakukan dengan berbagai pelatihan yang dilaksanakan secara online maupun offline. Kegiatan pelatihan yang dilakukan Dosen STKIP PGRI Lubuklinggau sebagai tim pelaksana ini akan memberikan pengalaman bagi Guru-guru Sejarah SMA di Lubuklinggau.

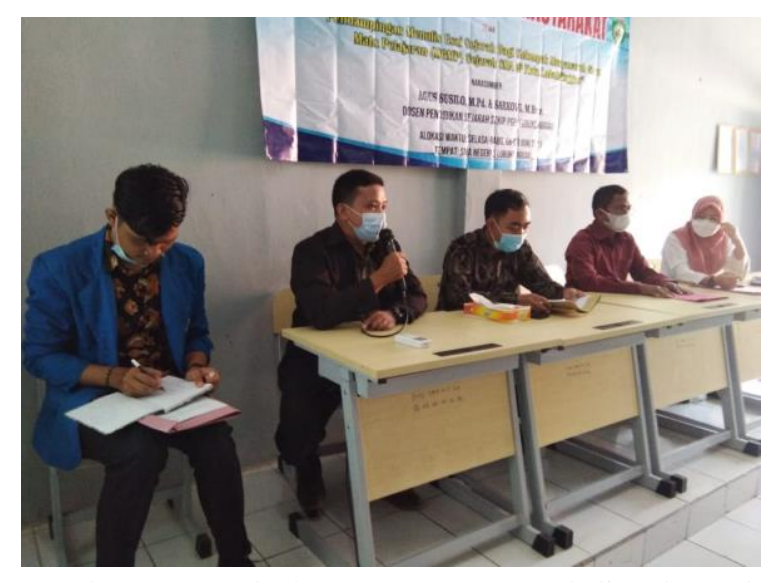

Gambar 1. Pembukaan Acara Pengabdian kepada Masyarakat 
657 Pendampingan Menulis Esai Sejarah Bagi Kelompok Musyawarah Guru Mata Pelajaran (MGMP) Sejarah SMA di Kota Lubuklinggau - Agus Susilo, Sarkowi, Yaswan Rilau Nisas, Abu Soli, Yuni Septalia

DOI: https://doi.org/10.31004/abdidas.v2i3.331

Dalam kegiatan pendampingan menulis esai Sejarah bagi kelompok Musyawarah Guru Mata Pelajaran (MGMP) Sejarah SMA Kota Lubuklinggau, tidak hanya berpusat pada pemateri saja, namun juga diselingi sesi tanya jawab dan praktik kegiatan menulis esai Sejarah. Kegiatan pengabdian kepada masyarakat dengan menulis esai Sejarah ini tentunya akan menambah wawasan dan manfaat bagi Guru-guru Sejarah di era milenial saat ini. Perlu dipahami bahwa menulis esai dapat juga diterapkan kepada siswa. Menulis esai Sejarah sering kali dijadikan kegiatan perlombaan yang mengangkat tokoh sejarah, kearifan lokal, dan yang berkaitan dengan sejarah.

Kegiatan pendampingan menulis esai Sejarah bagi kelompok Musyawarah Guru Mata Pelajaran (MGMP) Sejarah SMA Kota Lubuklinggau untuk membantu Guru-guru Sejarah agar dapat mampu mengembangkan bakatnya dan lebih berkreativitas dengan menulis esai. Esai dapat ditulis sesuai dengan bidangnya masingmasing. Bagi Guru Sejarah tentunya menulis esai yang berkaitan dengan Sejarah akan memberikan pengalaman yang baik. Dari hasil kegiatan pengabdian kepada masyarakat ini nantinya akan berupa hasil kegiatan atau laporan dan jurnal pengabdian kepada masyarakat. Secara rinci, kegiatan pendampingan menulis esai bagi Guru Sejarah SMA di Lubuklinggau ini bertujuan untuk membantu guru sebagai berikut: 1) memahami tentang esai Sejarah, 2) memahami teknik penulisan esai Sejarah, 3) berkeinginan kuat untuk mendesain dan menulis esai Sejarah, 4) mampu mengumpulkan sumber terkait esai Sejarah yang akan ditulis dan kembangkan, 5) mampu untuk menyajikan hasil tulisan esai Sejarah dalam bentuk laporan penelitian dan tulisan ilmiah.

Dalam kegiatan pengabdian kepada masyarakat ini didapatkan respon dari Guru-guru Sejarah, terkait beberapa permasalahan yang terekam, sebagai berikut:

1. Pada awal kegiatan pelaksanaan pengabdian kepada masyarakat, para peserta yang merupakan Guru Sejarah yang tergabung dalam Musyawarah Guru Mata Pelajaran (MGMP) Kota Lubuklinggau merasa rendah diri namun merasa tertantang untuk mengikuti kegiatan secara menyeluruh dan menghasilkan satu karya ilmiah berupa esai Sejarah.

2. Wawasan Guru Sejarah terhadap esai Sejarah masih sangat kurang.

3. Kemampuan Guru Sejarah dalam menulis esai Sejarah masih rendah.

4. Penggunaan sumber referensi untuk dijadikan rujukan terhadap esai Sejarah masih minim.

5. Kemampuan untuk menelaah dan menghindari plagiarisme terhadap sumber yang dijadikan rujukan masih sangat rendah.

6. Semangat menulis esai Sejarah yang menjadi salah satu pengembangan diri bagi Guru Sejarah masih sangat rendah.

7. Semangat belajar untuk mendapatkan hasil yang terbaik masih perlu ditingkatkan.

8. Daya serap dan daya tangkap peserta kegiatan pengabdian kepada masyarakat belum memuaskan. 
658 Pendampingan Menulis Esai Sejarah Bagi Kelompok Musyawarah Guru Mata Pelajaran (MGMP) Sejarah SMA di Kota Lubuklinggau - Agus Susilo, Sarkowi, Yaswan Rilau Nisas, Abu Soli, Yuni Septalia

DOI: https://doi.org/10.31004/abdidas.v2i3.331

9. Penyelesaian terhadap tugas-tugas yang diberikan pemateri masih lambat dan membutuhkan waktu yang cukup berbedabeda dalam menyelesaikannya.

10.Beberapa peserta masih ada yang memiliki kemampuan terbatas atau belum mahir dalam menggunakan teknologi.

Berdasarkan permasalahan-permasalahan yang dibahas di atas, maka kegiatan pengabdian kepada masyarakat dengan tema Pendampingan Menulis Esai Sejarah bagi Kelompok Musyawarah Guru Mata Pelajaran (MGMP) Sejarah SMA Kota Lubuklinggau untuk terus membina Guru Sejarah agar lebih terampil dalam merencanakan, melakukan, dan menyusun esai Sejarah yang baik dengan beberapa tahapan sebagai berikut:

Pertama, tahapan pemaparan materi yang terkait pendampingan menulis esai Sejarah bagi kelompok Musyawarah Guru Mata Pelajaran (MGMP) Sejarah SMA Kota Lubuklinggau. Materi-materi yang dipaparkan adalah materi terkait teknik penulisan esai dan menghindari plagiarisme. Materi tersebut dipaparkan dengan bantuan media PowerPoint. Isi materi yang terdapat di dalam PowerPoint lebih membahas pada teknik penulisan esai sebagai tulisan ilmiah.

Kedua, tahapan pelatihan. Pendampingan ini tidak sekedar hanya menayangkang pengertian esai Sejarah didalam materi PowerPoint, namun juga dilakukan pelatihan. Pelatihan penting untuk memberikan pengalaman bagi Guru Sejarah. Materi pendampingan penulisan esai Sejarah sebagai berikut: 1) esai Sejarah sebagai peningkatan kemampuan Guru Sejarah; 2) pengkalian terhadap sumber referensi yang dijadikan kajian pustaka; 3) penulisan esai Sejarah secara terbimbing; 4) penulisan esai Sejarah. Alokasi waktu pelatihan untuk kegiatan pelatihan ini adalah 18 Jam selama dua hari. Dokumentasi kegiatan pendampingan menulis esai terdapat pada gambar 1.

Tahapan ketiga adalah tahap pendampingan. Pendampingan ini bertujuan untuk mendampingi Guru Sejarah dalam menulis esai Sejarah yang baik dan benar. Pendampingan dilaksanakan oleh tim pelaksana yang merupakan Dosen STKIP PGRI Lubuklinggau kepada para Guru Sejarah yang tergabung dalam MGMP Sejarah. Bentuk pendampingan ini meliputi, yaitu: 1) Pelaksanaan penulisan esai Sejarah yang dikembangkan dengan beberapa masukan terhadap tulisan yang sedang dikerjakan atau memberikan arahan dalam kaitannya dengan tahapan refleksi. 2) Penulisan esai Sejarah dengan terus memberikan arahan terkait cara-cara penulisan esai Sejarah, dan 3) Penulisan esai Sejarah yang baik agar terhindar dari plagiat. Pengabdian kepada masyarakat yang bertema pendampingan menulis esai Sejarah ini berusaha untuk memberikan arahan dan bimbingan kepada guru agar terampil dalam menulis karya ilmiah esai. Pendampingan menulis esai Sejarah dilakukan oleh Dosen STKIP PGRI Lubuklinggau kepada Guru-guru Sejarah SMA di Kota Lubuklinggau. Kegiatan pendampingan ini dilaksanakan selama dua hari yang melibatkan dua Dosen dan beberapa Mahasiswa STKIP PGRI Lubuklinggau. Jumlah peserta yang hadir dalam kegiatan pendampingan ada berjumlah sekitar 20 
659 Pendampingan Menulis Esai Sejarah Bagi Kelompok Musyawarah Guru Mata Pelajaran (MGMP) Sejarah SMA di Kota Lubuklinggau - Agus Susilo, Sarkowi, Yaswan Rilau Nisas, Abu Soli, Yuni Septalia

DOI: https://doi.org/10.31004/abdidas.v2i3.331

orang Guru Sejarah. Tempat kegiatan pengabdian kepada masyarakat berada di Aula SMA Negeri 5 Lubuklinggau. Kegiatan pendampingan menulis esai Sejarah selanjutnya dapat dilihat dalam gambar 2.

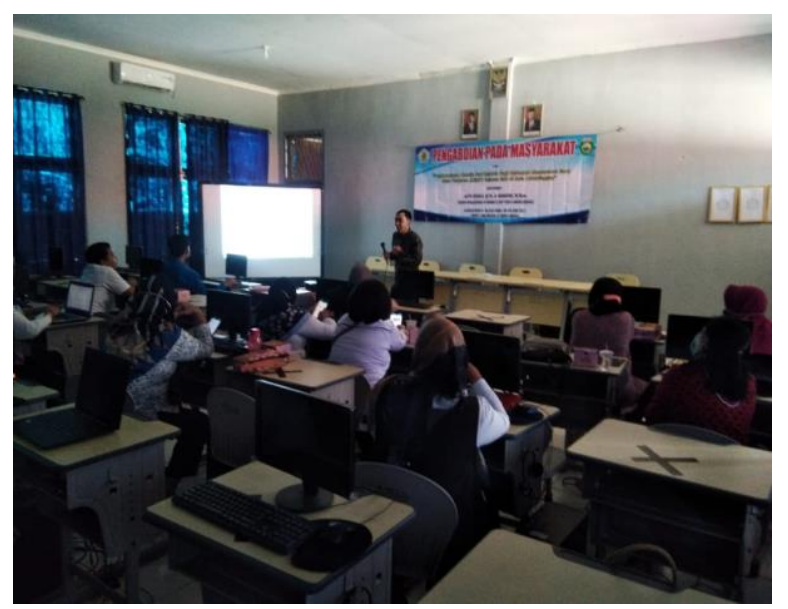

Gambar 2. Pelaksanaan Pengabdian kepada Masyarakat

Keempat, pendampingan secara online. Dalam kegiatan pendampingan secara online ini, peserta pendampingan selanjutnya dibimbing secara online agar maksimal dalam menyajikan laporan penulisan esai Sejarah. Dalam pendampingan secara online melalui grup WhatsApps ini nantinya akan diberikan masukanmasukan kembali terbaik esai Sejarah yang telah dianalisis tim pelaksana pendampingan. Berdasarkan tahap atau langkah yang dilakukan di atas, kegiatan pendampingan ini diperoleh hasil sebagai berikut:

1. Sebanyak 20 orang Guru Sejarah yang tergabung dalam MGMP Sejarah mengikuti pelatihan secara penuh dengan $18 \mathrm{Jam}$ atau dua hari pelaksanaan.
2. Terlaksana dua kali pendampingann dalam kegiatan perencanaan, pelaksanaan, dan penulisan esai Sejarah.

3. Tersedia 20 laporan esai Sejarah yang sendiri oleh setiap peserta dengan bimbingan dan arahan tim pendamping.

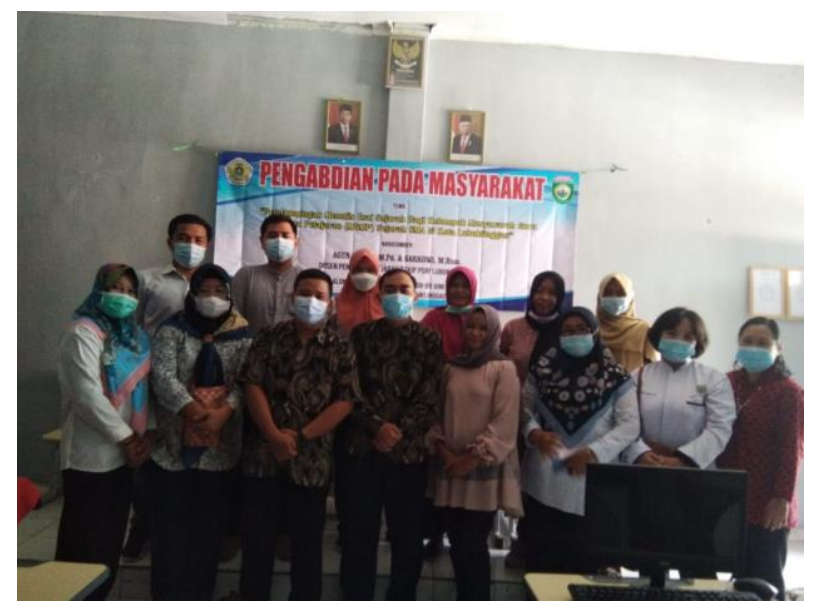

Gambar 3. Penutup Acara Pengabdian kepada Masyarakat

Selain memberikan pendampingan secara langsung, pendampingan terkait penulisan esai Sejarah ini juga dilakukan secara online melalui grup WhatsApp. Tujuan dari pendampingan lanjutan yang dilaksanakan melalui media sosial adalah sebagai wujud bahwa untuk memberikan ruang gerak bagi mitra yaitu MGMP Sejarah SMA agar Guru-guru Sejarah yang mengikuti kegiatan pendampingan dapat menerapkan penulisan esai Sejarah dengan baik dan dapat diterapkan kepada peserta didiknya. Jadi pendampingan yang dilaksanakan tidak terhenti pada saat kegiatan tatap muka berlangsung.

Setelah diadakan pelatihan tentang pendampingan menulis esai Sejarah bagi kelompok Musyawarah Guru Mata Pelajaran 
660 Pendampingan Menulis Esai Sejarah Bagi Kelompok Musyawarah Guru Mata Pelajaran (MGMP) Sejarah SMA di Kota Lubuklinggau - Agus Susilo, Sarkowi, Yaswan Rilau Nisas, Abu Soli, Yuni Septalia

DOI: https://doi.org/10.31004/abdidas.v2i3.331

(MGMP) Sejarah SMA di Kota Lubuklinggau, banyak guru-guru yang mulai terampil dan sangat kuat keinginannya mengembangkan esai sebagai pengembangan diri di dalam pembelajaran di kelas. Pihak sekolah sendiri juga sangat mendukung pengembangan diri para guru-guru demi kemajuan pendidikan di SMA dalam meningkatkan kreativitasnya. Selain itu, hasil evaluasi yang dilakukan tim pelaksana pengabdian kepada masyarakat untuk Musyawarah Guru Mata Pelajaran (MGMP) Sejarah SMA berupa hasil wawancara terhadap guru-guru yang mengikuti pelatihan menulis esai Sejarah. Pendampingan menulis esai Sejarah bagi kelompok Musyawarah Guru Mata Pelajaran (MGMP) Sejarah SMA di Kota Lubuklinggau. Agar pelaksanaan kegiatan pengabdian kepada masyarakat ini dapat lebih maksimal, maka pelaksanaan kegiatan juga dilakukan dengan secara online dengan grup WhatsApp untuk melihat hasil karya guru-guru yang telah mengikuti pelatihan. Guru-guru MGMP Sejarah menunjukkan antusiasnya yang sangat tinggi sehingga kegiatan pengabdian kepada masyarakat dinilai sangat berhasil dan memberikan manfaat bagi para Guru Sejarah di Lubuklinggau. Tentunya hal ini sangat bagus bagi dunia pendidikan dan semoga menjadi solusi bagi sistem pembelajaran Sejarah SMA di Lubuklinggau yang saat ini masih daring akibat wabah Covid-19.

\section{SIMPULAN}

Kegiatan pengabdian kepada masyarakat dengan tema pendampingan menulis esai Sejarah bagi Musyawarah Guru Mata Pelajaran (MGMP)
Sejarah SMA di Lubuklinggau ini mendapatkan respon yang baik. Beberapa Guru yang mengikuti kegiatan pengabdian kepada masyarakat sangat antusias dari awal pembukaan sampai penutupan. Dalam kegiatan pengabdian ini, beberapa poin yang dihasilkan adalah semangat para Guru Sejarah yang bertambah wawasannya tentang esai dan pengalamannya mendesain esai Sejarah menjadi karya ilmiah yang menarik. Esai Sejarah bukan sekedar tulisan biasa, namun bernilai tinggi.

Untuk membuat esai Sejarah memang sangat sederhana. Meskipun demikian kreativitas dan semangat dalam menulis harus tetap dikembangkan agar tulisan yang sederhana menjadi karya ilmiah yang dapat dilanjutkan pada akhirnya nanti. Dari kegiatan pengabdian ini, diketahui beberapa guru mulai menyukai teknik menulis esai Sejarah. Bahkan rasa semangatnya dalam membuat esai dapat diterapkan kepada peserta didiknya jika benar-benar sempurna esai Sejarah yang ditulisnya tersebut.

\section{UCAPAN TERIMA KASIH}

Kegiatan pengabdian kepada masyarakat ini merupakan bagian dari kewajiban dosen untuk melaksanakan Tri Darma Perguruan Tinggi di Kampus STKIP PGRI Lubuklinggau. Materi yang dikembangkan adalah pendampingan menulis esai Sejarah sebagai karya ilmiah yang dapat dikembangkan oleh Guru-guru Sejarah di SMA Lubuklinggau. Dalam kegiatan pengabdian yang berjalan dengan lancar ini, tim pelaksana mengucapkan terima kasih yang sebesar-besarnya kepada: 
661 Pendampingan Menulis Esai Sejarah Bagi Kelompok Musyawarah Guru Mata Pelajaran (MGMP) Sejarah SMA di Kota Lubuklinggau - Agus Susilo, Sarkowi, Yaswan Rilau Nisas, Abu Soli, Yuni Septalia

DOI: https://doi.org/10.31004/abdidas.v2i3.331

1. Bapak Dr. Rudi Erwandi, M.Pd selaku ketua STKIP PGRI Lubuklinggau yang telah memberikan motivasi dan dorongan kepada kami selaku dosen untuk meningkatkan produktifitas dan kualitas penelitian.

2. Bapak Viktor Pandra, M.Pd selaku kepala LP4MK beserta stafnya yang telah banyak memberikan dukungan, fasilitas, administrasi guna kelancaran penelitian.

3. Bapak Jamaludin, M.Pd. Selaku Kepala Sekolah SMA Negeri 5 Lubuklinggau yang telah memberikan tempat dalam kegiatan pengabdian kepada masyarakat.

4. Ibu Sisca Arie Hanika, S.Pd.,M.M., selaku ketua MGMP Sejarah SMA Lubuklinggau yang telah menjadi mitra dalam kegiatan pengabdian kepada masyarakat.

5. Teman-teman dosen, khususnya dari Program Studi Pendidikan Sejarah yang telah memberikan dukungan dan semangat dalam penyelesaian penelitian ini.

6. Pihak-pihak lainnya yang tidak bisa kami sebutkan namanya satu persatu yang telah membantu dalam penyelesaian kegiatan pengabdian kepada masyarakat.

\section{DAFTAR PUSTAKA}

Anggraini, A., \& Solihatulmilah, E. (2020). Peningkatan Keterampilan Menulis Esai Bahasa Indonesia Melalui Strategi Pemodelan. Jurnal Pendidikan Dasar Setiabudhi, 3(2), 70-77. Retrieved from https://stkipsetiabudhi.ejournal.id/jpds/article/view/85

Jumardi. (2020). Relevansi Nilai-Nilai Sejarah Lokal dan Nasionalisme Generasi Muda. Jurnal PENDIDIKAN SEJARAH, 9(1), 74-
89. Retrieved from http://journal.unj.ac.id/unj/index.php/jps/artic le/view/14269

Lubis, S. S. W. (2017). Keterampilan Menulis Esai Dalam Pembentukan Berpikir Kritis Mahasiswa Prodi PGMI UIN AR-Raniry Banda Aceh. PIONIR Jurnal Pendidikan, 6(2), $\quad 1-17$. https://doi.org/http://dx.doi.org/10.22373/pjp. v6i2.3338

Mustyka, O. (2016). Peningkatan Keterampilan Menulis Esai Melalui Model Cooperative Integrated Reading And Composition (CIRC). Jurnal Pendidikan Rokania, 1(2), 918. Retrieved from https://ejurnal.stkiprokania.ac.id/index.php/jpr/article /view/64

Nofiyanti, dkk. (2018). Penerapan Strategi Permainan Catalisting Yang Berorientasi Pada Kecerdasan Linguistik (PC-KL) Dalam Pembelajaran Menulis Esai. DEIKSIS Jurnal Pendidikan Bahasa Dan Sastra Indonesia, 5(1), 24-36. https://doi.org/http://dx.doi.org/10.33603/dei ksis.v5i1.733 